Anenburg, M., and Mavrogenes, J.A., 2020, Noble metal nanonugget insolubility in geological sulfide liquids:

Geology, v. 48, https://doi.org/10.1130/G47579.1

\title{
1 Noble metal nanonugget insolubility in geological sulfide liquids
}

2 Michael Anenburg, John Mavrogenes

3 Research School of Earth Sciences, Australian National University, Canberra ACT

42600 , Australia

\section{METHODS}

6 The silicate starting material was prepared by mixing NM-nanonugget bearing glass

7 fragments produced in a previous study (Anenburg and Mavrogenes, 2016) with

8 additional oxides to produce a mix of the composition: $54 \% \mathrm{SiO}_{2}, 12.4 \% \mathrm{Al}_{2} \mathrm{O}_{3}, 3.6 \%$

$9 \mathrm{Fe}_{2} \mathrm{O}_{3}, 14.7 \% \mathrm{CaO}, 3.9 \% \mathrm{MgO}, 3.6 \% \mathrm{Na}_{2} \mathrm{O}, 0.8 \% \mathrm{~K}{ }_{2} \mathrm{O}, 1 \% \mathrm{RbCl}, 1 \% \mathrm{CsCl}$, and $5 \%$

$10 \mathrm{H}_{2} \mathrm{O}$. The heavy alkali chlorides and high $\mathrm{H}_{2} \mathrm{O}$ content were added to produce a non-

11 viscous melt accessible at reasonable experimental temperatures $\left(1100^{\circ} \mathrm{C}\right.$, see

12 below). The NM and Bi budget is inherited from the starting glasses produced for the

13 Anenburg and Mavrogenes (2016) study. The use of $\mathrm{Bi}$ is justified for this study by its

14 non-toxicity (compared to other TABS such as As or Te), and by its use as a flux that

15 lowers the melting point of the refractory NM. Once in liquid form, the exact identity

16 of the TABS element bonded with the NM becomes less important as they are all in

17 solution within the liquid.

18 The sulfide starting material was prepared by melting an elemental mix of $25 \% \mathrm{Fe}$,

$1912.5 \% \mathrm{Ni}, 14.2 \% \mathrm{Cu}$, and $48.3 \% \mathrm{~S}$ in a graphite crucible for $\sim 1$ hour. Melting was

20 conducted at $900{ }^{\circ} \mathrm{C}$ in $\mathrm{N}_{2}$ atmosphere. Chromite was prepared by mixing

21 stoichiometric properties of $\mathrm{Cr}_{2} \mathrm{O}_{3}$ and $\mathrm{FeO}$ (prepared by reducing $\mathrm{Fe}_{2} \mathrm{O}_{3}$ in a 1-atm

22 furnace).

23 Graphite rods, $9 \mathrm{~mm}$ long and $4 \mathrm{~mm}$ wide, were used as capsule material. A $1.3 \mathrm{~mm}$

24 wide and $7 \mathrm{~mm}$ long hole was drilled into each rod, into which the starting materials 
were placed as layers. Three experiments are reported in this study: D2905 (consisting of $9.6 \mathrm{mg}$ of sulfide sandwiched between 7.4 and $3.6 \mathrm{mg}$ of silicate on the bottom and top, respectively), D2909 (consisting of $5.2 \mathrm{mg}$ of sulfide sandwiched between 5.3 and $7.6 \mathrm{mg}$ of silicate+chromite on the bottom and top, respectively), and C5774 (consisting of $5.2 \mathrm{mg}$ of sulfide sandwiched between 6.6 and $5.6 \mathrm{mg}$ of silicate on the bottom and top, respectively). A $2 \mathrm{~mm}$ thick graphite lid was placed on top of each rod, and the entire graphite assemblies were inserted into a swage-type $\mathrm{Ni}$ capsules with a wall thickness of $\sim 1 \mathrm{~mm}$ (Hack and Mavrogenes, 2006). The Ni capsules were then inserted into $10 \mathrm{~mm}$ wide $\mathrm{MgO}$ assembly, surrounded by graphite foils (to be used as heaters), and into a $19 \mathrm{~mm}$ talc sleeves. This design ensures that the experimental charge only contacts graphite. The Ni capsule allows containment of any $\mathrm{CO}_{2}$ gas produced during the reaction between ferrous iron and 37 graphite:

$$
2 \mathrm{Fe}_{2} \mathrm{O}_{3}+\mathrm{C}=4 \mathrm{FeO}+\mathrm{CO}_{2}
$$
In turn, the $\mathrm{CO}_{2}$ gas serves as the $\mathrm{fO}_{2}$ buffer in equilibrium with graphite. It is not clear whether pure $\mathrm{CO}_{2}$ gas existed in our experiments, but in any case the silicate melt was saturated or nearly saturated in $\mathrm{CO}_{2}$, thus buffering $\mathrm{fO}_{2}$ conditions to $\mathrm{CCO}$ or nearly so (Frost and Wood, 1997). The combined use of talc and graphite foil required that the maximum temperature is $1100^{\circ} \mathrm{C}$, because higher temperatures cause rapid degradation of the graphite foil.

The entire assembly was inserted into a $19 \mathrm{~mm}$ (3/4") pressure vessel, and run in an 46 end-loaded piston cylinder apparatus with automatic control of temperature and pressure using an in-house system. We used a piston-out method in which pressure was first increased to $5 \mathrm{kbar}$, and then temperature was increased at a rate of 
$100^{\circ} \mathrm{C} / \mathrm{min}$. Temperature was monitored via a type-B thermocouple. Runs D2905 and D2909 ran for 4 hours, and run C5774 ran for 17 hours. Experiments were quenched by turning off power to the heater, causing temperature to drop below 600 ${ }^{\circ} \mathrm{C}$ in $\sim 5$ seconds, and reaching room temperature in less than one minute. After each experiment, the capsules were removed from the assembly, mounted in 1" epoxy mounts and the experimental charges were exposed using a coarse diamond lap and sand paper. Final polishing was conducted using successively finer diamond pastes down to a grade of $0.25 \mu \mathrm{m}$.

Element maps were conducted using WDS spectrometers on a JEOL 8530F Plus field emission EPMA. Accelerating voltage was $8 \mathrm{kV}$ and beam current was $50 \mathrm{nA}$. Pixel size varied between maps but was commonly between 100 and $200 \mathrm{~nm}$, and dwell time per pixel was 250 ms. Maps were obtained in two passes, with S (KaPETJ), Ru (La-PETL), Ag (La-PETL), Pt (Ma-PETL) and Ni (La-TAPH) in the first pass, and Bi (Ma-PETJ), Pd (La-PETL), Au (Ma-PETL), Ir (Ma-PETL) and Cu (LaTAPH) in the second pass. $(\lambda=193 \mathrm{~nm}$ ), feeding into an Agilent 7700 ICP-MS. Sampling cell was a "HelEx" twovolume vortex cell in an atmosphere of $\mathrm{Ar}$ and $\mathrm{He}$, with $\mathrm{H}_{2}$ added during sample introduction to the ICP-MS. Spot size was $13 \mu \mathrm{m}$ and laser repetition rate of $3 \mathrm{~Hz}$. The following masses were measured: ${ }^{27} \mathrm{Al},{ }^{28} \mathrm{Si},{ }^{44} \mathrm{Ca},{ }^{52} \mathrm{Cr},{ }^{60} \mathrm{Ni},{ }^{63} \mathrm{Cu},{ }^{102} \mathrm{Ru},{ }^{103} \mathrm{Rh}$, ${ }^{106} \mathrm{Pd},{ }^{107} \mathrm{Ag},{ }^{193} \mathrm{lr},{ }^{195} \mathrm{Pt},{ }^{197} \mathrm{Au},{ }^{209} \mathrm{Bi}$.

\section{REFERENCES CITED}

Anenburg, M., and Mavrogenes, J.A., 2016, Experimental observations on noble metal nanonuggets and $\mathrm{Fe}-\mathrm{Ti}$ oxides, and the transport of platinum group elements in silicate melts: Geochimica et Cosmochimica Acta, v. 192, p. 258278, doi:10.1016/j.gca.2016.08.010. 
75 Frost, D.J., and Wood, B.J., 1997, Experimental measurements of the fugacity of $\mathrm{CO}_{2}$ and graphite/diamond stability from 35 to $77 \mathrm{kbar}$ at 925 to $1650^{\circ} \mathrm{C}$ :

Geochimica et Cosmochimica Acta, v. 61, p. 1565-1574, doi:10.1016/s00167037(97)00035-5.

Hack, A.C., and Mavrogenes, J.A., 2006, A cold-sealing capsule design for synthesis of fluid inclusions and other hydrothermal experiments in a piston-cylinder apparatus: American Mineralogist, v. 91, p. 203-210, doi:10.2138/am.2006.1898. 